Zabytkoznawstwo i Konserwatorstwo XLI, Toruń 2011

Katarzyna Kulpińska

\title{
Rola przestrzeni w pejzażach Piotra Potworowskiego*
}

$\mathrm{J}$ estem człowiekiem, który bada głębię przestrzeni"1 - te słowa Piotra Potworowskiego, artysty, którego los obdarzył dwiema ojczyznami, stanowią esencję jego twórczych wysiłków. Przed wojną kapista, wychowanek Pankiewicza, fascynujący się malarstwem Bonnarda i Matisse'a, uczeń Légera, po wojnie osiadł w Anglii, gdzie poświęcił się intensywnej pracy - jako artysta (został członkiem prestiżowej London Group) i pedagog (objął stanowisko profesora Bath Academy of Art w Corsham). Wszechstronna działalność mistrza Piotra (malarstwo, rysunek, kompozycje przestrzenne, scenografia) miała także odpowiednik w innej materii - słowa. Wiersze, listy, niezwykle cenne zapiski ze szkicowników, luźne notatki artysty pozwalają na wgląd w jego „piękny umysł” - zapraszają do zgłębienia najbardziej osobistych przeżyć, odczuć, towarzyszą realizacjom plastycznym, odkrywając ich drugie dno. Obrazy Piotra Potworowskiego to świadectwa jego nieustannych zmagań z przestrzenią, formą, barwą. Emocje, chwile, wrażenia, poddane artystycznej syntezie, przetworzone zostały w ponadczasowe wartości, zaklęte na płótnie zapisy - kody. Myśl Potworowskiego - żywa we wszystkich jego obrazach, szkicach, słowach - inspiruje kolejne pokolenia adeptów sztuki. Jak mawiał sam mistrz, są „trzy okresy tworzenia obrazu

* Referat pt. The Role of Space in Piotr Potworowski's Landscapes wygłoszony został 1 maja 2008 r. podczas międzynarodowego malarskiego pleneru poświęconemu Piotrowi Potworowskiemu (z okazji 110. rocznicy urodzin malarza) w Kazimierzu Dolnym. Plenerowi zorganizowanemu przez prof. art. mal. Mieczysława Ziomka (Wydział Sztuk Pięknych UMK) towarzyszyła wystawa prac Potworowskiego pt. Wisła w Muzeum Nadwiślańskim. Niniejszy artykuł stanowi przeredagowaną wersję tego referatu.

1 P. Potworowski, Szkicowniki, 1950-1951. 
- ten ostatni to działanie obrazu w czasie, który trwa czasami tysiące lat"2. Patrząc na prace Potworowskiego, stajemy się więc uczestnikami - współtwórcami trzeciego, niezwykle istotnego, zdaniem artysty, etapu. Kontynuujemy jego dzieło, podejmując trud wczytania się w ślady, znaki, słowa pozostawione przez mistrza, szczególnie w miejscu, które było mu tak bliskie - w nadwiślańskim Kazimierzu.

Rozważania niniejsze dotyczyć będą twórczości pejzażowej Piotra Potworowskiego, której fenomen w dużej mierze tłumaczy podejście artysty do zagadnień przestrzeni. Wielokrotnie będę tu przywoływać wypowiedzi mistrza, aby uniknąć streszczenia czy interpretacji tego, co On sam ujął najtrafniej: „Chodzi o to, ażeby dojść z malarstwem swoim do ściany - nic więcej. Do ściany świata [...] Na granicy świata” Pojęta tu jako kraniec możliwości i synonim dotarcia do celu metaforyczna „ściana” była dla artysty codziennym wyzwaniem, podejmowaną w każdym obrazie próbą.

Potworowski postrzegał płótno w kategoriach czysto malarskich: światła (obraz powinien być „potężnym aparatem recepcyjnym fal światła"4), barwy (jako „najpotężniejszego czynnika malarstwa”5) i przestrzeni, którą definiują formy i relacje między nimi.

Koncepcja przestrzeni Potworowskiego wynika z kilku najistotniejszych, wyznawanych przez niego zasad. Po pierwsze, zrywając z tradycyjną metodą malowania $\mathrm{z}$ jednego punktu, artysta ujmował pejzaż jako sumę zjawisk obiektywnych i subiektywnych; to, co zobaczył i odczuł, przetwarzał w "trafny fakt malarski”. W tym kontekście, podejmował się nowej organizacji przestrzeni na swych płótnach; relacje przestrzenne stawały się efektem „głębszego zobaczenia”. Potworowski określał to tak: „[malować] jak najbardziej obiektywnie, jak najbardziej szeroko, wyrzekając się przyzwyczajeń i konwencji; wydaje się, jakby

2 P. Potworowski, List do T. Pągowskiej z 16 września 1958 r., Poznań (cyt. za: Piotr Potworowski 1898-1962, Warszawa 1998, s. 225).

3 Fragment wypowiedzi z 1958 r., cyt. za: Wypowiedzi o malarstwie. Ze szkicowników P. Potworowskiego, „Sztuka” 1977, nr 2-4, s. 1.

4 Fragment wypowiedzi artysty, Szkicowniki, 1958-1960, t. V.

5 Ibidem.

6 Określenie I. Moderskiej, O Piotrze Potworowskim w okresie angielskim 1940-1958, w: Piotr Potworowski 1898-1962. 
ten fragment natury zaobserwowanej był czymś abstrakcyjnym, ale nim nie jest, jest nowym, głębszym zobaczeniem" ". Po drugie, indywidualne szyfrowanie zaobserwowanych i „oswojonych” relacji przestrzennych. Przestrzeń w obrazach artysty to nie przestrzeń „Zastana”, a raczej nie tylko zastana, ale też przefiltrowana przez wrażliwość mistrza, poddana uogólnieniu, zweryfikowana przez czas. Ten dystans czasowy, kilkugodzinny czy kilkudniowy, pozwalał na syntezę, odgrywając istotną rolę w procesie twórczym. Procesie, który dla Potworowskiego miał przede wszystkim aspekt intelektualny, a dopiero w jego następstwie wymiar artystyczny. Po trzecie, przestrzeń na płótnie Potworowskiego to efekt „właściwych rozwiązań chromatycznych”8 - umiejętność „budowania dowolnych relacji przestrzennych za pomocą kilku barwnych płaszczyzn" " Znaczenie obiektu o tyle jest istotne, o ile wchodzi on w relacje z innymi elementami, tworząc kategorie przestrzenne: „Cała moja uwaga koncentruje się na roli, jaką odgrywają w tworzeniu przestrzeni fragmenty przedmiotów, które widzę. Przedmioty nie istnieją już same dla siebie. Ten rodzaj malarstwa nie ma wyraźnie ustanowionego tematu. To otwiera Drzwi" ${ }^{\prime 10}$. Drzwi percepcji - chciałoby się dodać...

Malarstwo było postrzegane przez Potworowskiego jako najdonioślejsza próba wyrażenia przestrzeni: „Malarstwo będąc zgłębianiem jakości przestrzeni, bardziej jest rozumieniem przestrzeni jako trwałego elementu, w którym istniejemy. Przestrzeń możemy postrzegać tylko poprzez wzajemne relacje form"11. Każdy pejzaż artysty jest syntezą - umiejętnością „wszechogarnięcia” elementów stałych danego krajobrazu oraz ulotnych stanów, doświadczeń, przeżyć wobec tego właśnie wycinka natury. Umiejętność „Zakodowania” cech pewnej przestrzeni oraz sumy wrażeń składających się na dogłębnie „obejrzany” i intelektualnie spenetrowany krajobraz w niepowtarzalny szyfr na płótnie - to niezwykły wyróżnik twórczości Piotra Potworowskiego. Zwłaszcza że umiejętność tę łączył z darem oddania specyfiki danego miejsca na zie-

7 P. Potworowski, Szkicowniki, 1960-1961, t. VI, notka z 23 września 1960 r.

8 I. Moderska, O Piotrze Potworowskim w okresie angielskim 1940-1958, s. 37.

9 Ibidem.

10 P. Potworowski, Szkicowniki (tzw. Black Sketchbook); zapis z 7 czerwca 1951 r.

11 P. Potworowski, Szkicowniki, 1952, notka z czerwca [bez daty dziennej]. 
mi prostym, lecz bardzo celnym zabiegiem - „spotęgowaną”, zsyntetyzowaną tonacją barwną.

„Pierwszy, wyjściowy kolor w obrazie jest niezależnie czysty, nie jest zmuszony do przedstawiania czegokolwiek oprócz Siebie. Dopiero inne łamane kolory zaczynają przez swoją grę układu tworzyć formę. Formę podległą temu pierwszemu, nie skażonemu żadną funkcją czystemu światłu przybyłemu z zewnątrz" ${ }^{\prime 2}$ - pisał artysta w liście do przyjaciela, Zdzisława Kępińskiego. Potworowski definiuje przestrzeń na płótnie przez wzajemne oddziaływanie zestawień barwnych płaszczyzn. Uchwycenie tej przestrzeni było procesem intelektualnym i zmysłowym; czasem impulsywnym, intensywnym jak błysk, czasem mozolnym, długotrwałym (wymagającym nawet wielokilometrowych marszów) dążeniem do poznania i dokładnego zbadania specyfiki, istoty przestrzeni danego miejsca. Nie sposób tu nie wspomnieć o pewnym znamiennym przykładzie, który doskonale obrazuje zamysł mistrza zgłębienia nie tylko relacji przestrzennych, ale równocześnie usiłowania, aby oddać jak najpełniejszy obraz zjawiska, żywiołu. Artysta relacjonując swe artystyczne zmagania $\mathrm{z}$ Wisłą ${ }^{13}$, pisał: „Powoli i z trudem maluję ten leżący pejzaż. [...] Jest on w pewnym sensie charakterystyczny, ale trzeba diabelskiego wysiłku, żeby go chcieć. Dlatego muszę chodzić po kilkanaście kilometrów, żeby choć kawałek tego kraju zobaczyć jako całość, z głową i ogonem [...]. Nie udało mi się zobaczyć głowy Wisły, tylko jej niekończący się brzuch"14.

Potworowski wrócił do Polski z ogromnym bagażem doświadczeń życiowych i artystycznych. Krąg przyjaciół artystów z Bath Academy of Art (Clifford Ellis, Peter Lanyon, William Scott, Bryan Wynter, Adrian Heath, Kenneth Armitage, Lynn Chadwick), kilkunastoletnie zgłębianie angielskiego pejzażu, szczególnie bliski i emocjonalny kontakt z przyrodą Kornwalii, miały fundamentalne znaczenie dla kierunku poszukiwań i ostatecznej koncepcji pejzażu Piotra Potworowskiego. Przede

12 P. Potworowski, List do Z. Kępińskiego, z 11 grudnia 1961 r., Sopot (cyt. za: Fragmenty listów P. Potworowskiego do Z. Kępińskiego 1958-1962, „Sztuka” 1977, nr 2-4, s. 3).

13 Obraz pod tytułem Wisła $w$ Kazimierzu z $1961 \mathrm{r}$.

14 P. Potworowski, List do Z. Kępińskiego, z 15 sierpnia 1961 r., Kazimierz Dolny (cyt. za: Fragmenty listów P. Potworowskiego do Z. Kępińskiego, s. 3). 
wszystkim jednak na nowe wartości pejzażu otworzyła artystę twórczość przyjaciela, Petera Lanyona, choć kierunek wpływów nie był tylko jednostronny. Kenneth Coutts-Smith pisał: „Jestem przekonany, że korzyść, jaką wynieśli z wzajemnych kontaktów Lanyon i Potworowski, była obustronna i wyrównana, zasilająca wyobraźnię i talent obu malarzy"15. Brytyjski krytyk upatrywał specyfikę dojrzałej palety Lanyona w „swoiście kontynentalnej wrażliwości kolorystycznej”"16, wywodzącej się od Bonnarda, Vuillarda, Pankiewicza i Cybisa, której spadkobiercą był Potworowski. Jednocześnie wskazał „bezpośrednią i quasi-mistyczną wrażliwość Lanyona na fizyczną obecność ziemi" ${ }^{17}$ jako wartość oddziałującą na wizję Potworowskiego.

Tak jest istotnie; żywioł, obojętnie czy będzie to woda, czeluść lasu, czy spieczona skwarem ziemia, staje się w obrazach Potworowskiego bytem o wyrazistych, niepowtarzalnych cechach, a jednocześnie jedynej w swoim rodzaju aurze. Sposób, w jaki artysta definiuje właściwości przestrzeni, światła, barwy, obiektu, jest natury zarówno emocjonalnej, jak i intelektualnej. Krajobraz lub jego wybrany wycinek ujrzany, przeżyty, a w końcu przeanalizowany, w momencie stawania się na płótnie jest już „skondensowany” - sprowadzony do samej esencji, rdzenia, sedna. Stanowi kwintesencję zarówno zjawiska natury, jak i procesu twórczego - „wyciągania idei plastycznej”. Potworowski w idealny sposób potrafił uchwycić i określić genius loci danego miejsca. Wydaje się, że działał $\mathrm{w}$ tym zakresie $\mathrm{w}$ warstwie podświadomości, impulsu. Chwytał istotę miasta, rzeki, leśnego zakątka najprostszymi środkami malarskimi. Toskania, Siena, Tarragona, nadbrzeże Bałtyku, wulkan Stromboli, ogród w Corsham, las w Kornwalii, wodospad niedzicki - zyskują w obrazach Potworowskiego swój portret uniwersalny. Artysta stał się swojego rodzaju kolekcjonerem tych miejsc i związanych z nimi ulotnych, podlegających emocji i intuicji „składników”. Charakter, klimat, jakiś pierwotny duch danego miejsca czy żywiołu oddawał szyfrem barwy, gry przestrzennej, uproszczonego znaku. Ten system elementów

15 K. Coutts-Smith, Note on Peter Potworowski, Winnipeg, 1976, April, 30th; cyt. za: I. Moderska, Piotr Potworowski 1898-1962, Kalendarium, s. 218.

16 Ibidem.

17 Ibidem. 
odpowiadających konkretnej przestrzeni, którą obserwuje i wchłania artysta - sięga do korzeni, do praźródeł - może nawet do warstwy podświadomości zbiorowej. W Lascaux artysta doznał artystycznego olśnienia („Cała tajemnica malarstwa odsłoniła mi się w grotach Lascaux” ${ }^{18}$ ), które stało się także ważnym etapem na drodze samopoznania, o czym Potworowski wspomina w Szkicownikach: „Podświadomość zacząłem otaczać najtroskliwszą opieką, zrobiłem z niej przedmiot kultu, uznałem jej nieomylność"19.

Oczywiste jest w tym kontekście, że warunkiem wszystkich działań Potworowskiego był autentyzm przeżycia i przekonanie, że „pełny" obraz nie może powstać w emocjonalnej pustce. Dopuszczenie do głosu podświadomości nie oznaczało całkowitego zerwania z chłodną, intelektualną spekulacją. Stworzenie systemu znaków odpowiadających przestrzeni, którą obserwuje artysta, to swoiste szyfrowanie działało na obu poziomach: zmysłowo-emocjonalnym i intelektualnym: „Moim celem jest odkrycie nowych znaczeń obrazowanej przestrzeni" ${ }^{20}$. Takie zgłębianie przestrzeni, w wielu warstwach znaczeniowych tego słowa, wykluczało całkowicie opisowe jej traktowanie. Wartością nadrzędną jest „synteza bezpośredniego, zmysłowego odbioru fragmentu krajobrazowego"21, o czym pisał Zdzisław Kępiński, a co za tym idzie, specyficzne zabiegi formalne, jak np. pozorne odwracanie stosunków przestrzennych we fragmentach płótna ${ }^{22}$. Potworowski, którego główną zasadą było unikanie oczywistości w malarstwie, doskonale ujął to w słowach: „Rozpłaszczanie natury zaobserwowanej wprost na płótno jest absurdem [...] Bezpośrednia obserwacja jest konieczna po to, ażeby zachować jej wielki sens. Ale tylko rozbijając jej płaskość i konstruując na nowo według zasad przestrzeni trójwymiarowej można zrobić obraz"23. Te podejmowane po stokroć próby dotarcia do granicy poznawalnego

18 P. Potworowski, Szkicowniki, 1952.

19 Idem, Szkicowniki, 1958-1960, t. V.

20 Idem, Szkicowniki, zapis z 6 kwietnia 1951 r.

21 Z. Kępiński, Piotr Potworowski, Warszawa 1978, s. 31.

22 Zdaniem Kępińskiego „silniejszy bodziec wzrokowy z dalekiego planu wysuwa się na bliski, a coś, co słabo pobudza oko, choć jest blisko oka, ucieka gdzieś na daleki plan”. Ibidem, s. 21.

23 Ibidem. 
uzmysławiają jeszcze jeden ważny aspekt analizy przestrzeni: obserwowanie i studiowanie przedmiotów w bezpośrednim zasięgu widzenia: „badanie [przestrzeni] musi być dokonane na obiekcie, który znajduje się blisko mnie, który mogę obserwować i studiować” ${ }^{24}$. Odzwierciedla tę ideę z pewnością Wóz w Kazimierzu, obraz, który fragmentem pojazdu, motywem koła i drogi przywołuje cały pejzaż kazimierzowski $\mathrm{z}$ „ciepłym nasłonecznionym kurzem zalegającym na drogach” 25.

Tak więc obserwacja jako punkt wyjścia, notowanie emocji wyzwolonych w trakcie obserwacji natury i charakteru konstrukcji przestrzennych, światła, barw jako etap kolejny, a następnie refleksja - to proces uzyskiwania z tego ogromu bodźców, wrażeń, analiz, z bezpośredniego swojego doświadczania - esencji. Esencja ta - skondensowana, zaklęta na kilkudziesięciu centymetrach kwadratowych płótna - ma moc przywoływania i przenoszenia do utrwalonych artystycznie przestrzeni. W tym rozumieniu zsyntetyzowana kompozycja nabiera cech czystego „destylatu”, natomiast Piotr Potworowski staje się cierpliwym, niestrudzonym a zarazem zachłannym badaczem i kolekcjonerem wielu miejsc, widoków, wrażeń: „Połknąć, pochłonąć zachody słońca i przestrzeń pomiędzy drzewami zielonymi i wodą i stojące niebo niewiadomego koloru. Wszystko uważnie, ostrożnie zebrać, dzień po dniu, ażeby spróbować nagle, jednym tchem zamienić na magiczny znak-słowo, jakby krótki krzyk wieczorem, przed nocą, ptaka głosem"26. W tych słowach mistrza drzemie i pasja, i kontemplacja. Stanisław Frenkiel twierdził, że „Potworowski techniką i wrażliwością zbliżył malarstwo do muzyki" ${ }^{27}$. Wydaje się, że artysta posiadał po prostu cechy synestety: słyszał grę barwnych akordów, przestrzeń ujmował jako rytmiczną sekwencję form, żywioł określał kilkoma celnymi znakami, każdy kraj jawił mu się w innej gamie kolorystycznej.

Szczególną jednak fascynację Piotra Potworowskiego budził żywioł wody. Zaczynając więc od tego elementu, przyjrzyjmy się kilku

24 P. Potworowski, Szkicowniki (tzw. Black Sketchbook) z lat 1951-1953.

25 K. Kostyrko, Realizm ogarniający, „Sztuka” 1977, nr 2-4, s. 6.

26 P. Potworowski, Szkicowniki, 1958-1960, zapis z 24 czerwca 1959 r. (cyt. za: Wypowiedzi o malarstwie. Ze szkicowników P. Potworowskiego, s. 1).

27 S. Frenkiel, Kożuchy w chmurach i inne eseje o sztuce, Toruń 1998, s. 252. 
pracom opartym na specyficznym kodzie przestrzeni. Wodospad w Niedzicy (1960) to kwintesencja żywiołu sprowadzonego w swym ruchu do „migawki” obrazu utrwalonego w oku w ułamku sekundy. To widok zarejestrowany też w podświadomości - a na płótnie notacja żywego, będącego w nieustannym ruchu bytu natury. Notacja, która możliwa jest tylko na granicy twórczej syntezy. Podobnie monumentalna w efekcie uogólnienia jest znakomita kompozycja w owalu Twarz morza (1960). Relacje przestrzenne są tu rozegrane na bazie zderzenia gwałtownego żywiołu morskiego z elementem „obcym”, stałym (kadłubem łodzi lub pniem drzewa), niezwiązanym organicznie z wodą. Bryła, forma tego obiektu ingeruje w homogeniczną strukturę wody, wchodzi w relację z jej głębią. O ile mamy tu do czynienia raczej ze starciem niejednorodnych struktur, o tyle przejrzystość, wielowarstwowość, migotliwość wody osiągnęły apogeum we wcześniejszych obrazach - Czarna łódź (1957) i Kornwalia (ok. 1956). Bogactwo materii, mistrzowskie różnicowanie faktury wynika także z konfrontacji właściwości wody i czarnych obiektów. W Kornwalii synteza sprowadza się do gwałtowności żywiołu, w Czarnej łodzi - do spokojnej tafli. Woda została tu określona na kilka różnych sposobów, jako element nierozerwalnie związany z konkretnym miejscem i czasem.

Kanat $w$ lesie (ok. 1957) natomiast to próba zgłębienia skomplikowanych relacji przestrzennych dwóch elementów: zmiennego (wody) i stałego (stromych ścian kanału). Płótno to wciąga widza w głąb, prowadząc jego napięte zmysły aż do punktu granicznego - momentu, w którym linię wody przecinają i definitywnie tamują zwarte ściany lasu ograniczającego kanał, by w największym natężeniu kumulacji wody dać swobodny przepływ szeroko rozlanej trójkątnej plamy. Jest tu napięcie, ale też harmonia dwóch przeciwstawnych żywiołów. Rzeka sprowadzona do dwóch błękitnych, stykających się wierzchołkami trójkątów to moment przesilenia doprowadzony do granic ostatecznego napięcia. Powstaje struktura czterech współzależnych od siebie klinów błękitu i zieleni. Warto tu zwrócić uwagę na charakterystyczny znak, jakim jest reminiscencja śluzy - czarna forma zbudowana z najprostszych elementów geometrycznych: koła i prostokąta, który swą horyzontalną linią z wertykalnymi podziałami łagodzi w pewnym stopniu napięcie 
kompozycji ${ }^{28}$. Strukturę kompozycji Kanału współtworzą intuicyjne, organiczne w swym charakterze znaki zwielokrotniające swe odbicie $\mathrm{w}$ wodzie oraz dwie ekspresyjne, syntetycznie ujęte sylwety ludzkie. Przestrzeń jest tu dynamiczna, ale pewne zabiegi artysty zmierzają ku równowadze, ku podkreśleniu charakterystycznych, stałych wartości tego miejsca.

Nieodmiennie inspirująca była dla Potworowskiego Wisła. Artysta pokonywał kilometry, podążając jej biegiem, aby zgłębić charakter kapryśnej rzeki. Wisła $w$ Kazimierzu z 1959 roku to zamknięta w owalu intelektualna „rozgrywka” z pejzażem; próba pewnej systematyki elementów zastanych, a następnie przetworzonych. Natomiast obraz o tym samym tytule z 1961 roku to właśnie ten „niekończący się brzuch” rzeki ze wspomnianych już notatek malarza. Jest tu synteza leniwie toczącej się wody i nadbrzeżnego pejzażu. Intelektualne i emocjonalne rozpoznanie bogactwa barw i form, przeradza się tu w definiowanie relacji przestrzennych jako swoistej wspólnoty płaszczyzn, wzajemnego przenikania się, starcia brzegu z rzeką. W innej pracy z tego samego roku artysta ukazuje odmienne oblicze rzeki. Powódź na Wiśle, kompozycja zamknięta w owalu to gra zieleni i błękitu: pierwotnego, nieokiełznanego żywiołu z czernią dynamicznych znaków - obiektów migających przez chwilę nad powierzchnią rozlewiska i pogrążających się znów w odmętach. Ryba, drzewo, sprowadzone do maksymalnie prostych, a jednocześnie czytelnych układów linii, trafnie charakteryzują nieokiełznany charakter żywiołu.

Tę umiejętność zastosowania celnego skrótu dla charakterystyki obiektu podziwiała Teresa Pągowska, uczennica Piotrowskiego: „Dech zapierało, jak on rysował. Jak używał znaku najwłaściwszego" ${ }^{29}$. Idąc dalej tropem Wisły Potworowskiego: Zielona Wisła (1960) jest syntezą zieloności pól i wody z lotu ptaka. Łączy w sobie fascynujące artystę w najwyższym stopniu dwa żywioły: wody i zieleni (o Tajemnicy Zieleni pisał artysta jak alchemik w tomie VI Szkicowników z lat 1960-1961).

28 Tego typu szyfry pojawiają się także w pracy Fragment Jeziora Łagowskiego (1959-1960).

29 T. Pągowska, Bywał jak czarna chmura, „Tygodnik Powszechny” 1996, nr 49 , s. 12 . 
Wszechogarniająca zieleń form wyznacza rytm obrazów: Zielony most (1957) z bardzo sugestywnie oddaną głębią między przęsłami mostu, Pejzaż $z$ Łagowa (1958), Liściasty krzyż (1959). W tych dwóch ostatnich gra trójkątnych, dopełniających się form buduje przestrzeń - zieloną, namacalną głębię kryjącą przed wzrokiem odbiorcy kolejne warstwy gąszczu listowia czy mozaiki pól. W pracach tych rytmizującą rolę odgrywają czarne znaki - echa różnorodnych form natury - które są jednocześnie punktami odniesienia w zieloności. Zieleń soczysta, świeża, wciągająca widza w głąb to nie efekt zachłyśnięcia się polskim pejzażem. Odkrycie zieloności jako kategorii samej w sobie to przygoda angielska - świadczy o tym przesycone zielenią Wnętrze lasu. Kornwalia (1952) z geometryzującymi bryłami zwartych koron drzew, Pejzaż $z$ Wiltshire (Zielone wzgórze) - 1953 z monumentalną, łagodną bryłą zieloności pagórka, Las przed domem (1957) z zygzakiem prowadzącej w głąb zieleni ścieżki i wiele innych prac. Nie bez powodu w literaturze dotyczącej twórczości Potworowskiego funkcjonuje pojęcie „okres zielony”. Ale fascynacja zielenią nie ustaje w momencie powrotu artysty do Polski. Wystarczy zagłębić się w konstrukcję mrocznozielonej kompozycji Czarne i zielone łuki. Niedzica (1959) transponującej sczepione ze sobą wierzchołki drzew w sklepienie ogromnej katedry. Przestrzeń pogłębiona w nieskończoność zwielokrotnionymi, rytmicznymi łukami czerni to najdoskonalsza forma syntezy, podobnie jak niesamowita symfonia drzew; muzyczna ${ }^{30}$ struktura zieleni przecinanej rytmicznymi pionami i skosami czerni i ugru - w obrazie Las (1960-1962).

W obrazach upału, suszy i spiekoty przestrzeń zyskuje inny wymiar, wydaje się niekiedy brnięciem w niekończącą się pustkę - decyduje o tym między innymi relacja kolorystyczna jałowej ziemi i ołowianego nieba w Krajobrazie z Tarragony (1954), kwintesencja upalnego, sennego popołudnia w Uliczce w Hiszpanii (1954) ${ }^{31}$. Najwyższą temperaturę osiąga artysta w drgającym od upału powietrzu czerwonej Sieny (1955)

$30 \mathrm{Na}$ marginesie chciałabym tu przywołać twórczość młodopolskiego artysty, Mikołaja Konstantego Czurlanisa (Čiurlionisa), muzyka i malarza, który poruszał się w podobnych obszarach wrażliwości muzyczno-plastycznej; dość przywołać jego Fuge (1907) czy prace z cyklu Etiuda (1907-1908) i Lato z tego samego okresu.

31 Stagnację podkreśla tu dodatkowo zabieg wkomponowania czarnych, zastygłych jakby na wieczność sylwet krzeseł. 
czy Zachodzie słońca $w$ Toskanii (1956), gdzie budujące przestrzeń formy scharakteryzowane zostały zróżnicowanymi, choć zdominowanymi gamą gorących barw fakturami. Doświadczenia z licznych podróży po Włoszech, Hiszpanii, Francji, bagaż tylu miejsc, pejzaży, wrażeń, barw nie przełożyły się jednak na grunt polski. Zachód słońca w Kazimierzu (1958-1959) o takiej samej intensywności barw, wnikliwości obserwacji proponuje jednak inną koncepcję przestrzeni. Horyzontalne, rytmiczne pasma ciepłych barw gasnącego na horyzoncie słońca dają poczucie wszechogarniającego ciepła, wydają się gęste, tkane jak materia - być może są już podświadomą intencją późniejszego wykorzystywania motywu „pasiaków” na szerszą skalę.

W czerwcu 1958 roku, niemal dokładnie przed pięćdziesięciu laty, Potworowski przywitał Polskę jako dojrzały, doświadczony malarz o ogromnym i wartościowym dorobku artystycznym. Wyjeżdżał jako młody kapista - powrócił z całkowicie nową, świeżą koncepcją malarstwa. Prestiżowe wystawy (Biennale weneckie, Documenta w Kassel), praca pedagogiczna w Poznaniu i Sopocie, niezliczone powroty do Kazimierza nad Wisłą wyznaczyły nowy rytm życia artysty. „Czy jestem geniuszem? Moje obrazy stają się młode i świeże, podczas gdy ja się starzeję..."32 - zanotował mistrz Piotr, nie wiedząc zapewne, że słowa te będą aktualne także wiele lat później, po jego śmierci. Dzieło Piotra Potworowskiego pozostaje młode i świeże tą świeżością, emocją, esencją sumy przetworzonych wrażeń, jaką tchnął artysta w obraz w chwili jego powstawania: „Artysta nie maluje pejzażu, lecz stwarza go w umyśle człowieka"33. Każdy obraz Potworowskiego jest nośnikiem energii - jest energią samą w sobie. Daje olśnienie jak krótkie spięcie, jak błyskawica - w ułamku sekundy trafia do nas wielowarstwowy przekaz. Sprawdza się życzenie artysty co do widza: „musi on doznać emocji przeze mnie odczutych tak, jakby sam je odkrył”34. Otwarcie się na tę sztukę oznacza wchłonięcie nie tylko barwy, kształtu, przestrzeni ale także ułamka, refleksu tej intensywności, której doświadczał malarz: „Czasem udaje mi się zacząć obraz prawie z niczego, ale zawsze to prawie nic jest jakąś

32 P. Potworowski, Szkicowniki, zapis z 15 stycznia 1952 r.

33 Idem, Szkicowniki, 1959-1961, t. VI.

34 Ibidem; fragment z 22 października $1961 \mathrm{r}$. 
obserwacją świata - fragmentu świata, który zobaczyłem nagle i bardzo intensywnie"35.

Piotr Potworowski wierzył, że obrazy nie są tylko obiektami. Są wiadomościami, takimi jak książki. Odczytajmy je dla siebie, tak jak przed nami i po nas będą zgłębiać je ci, dla których twórczość tego przenikliwego, mądrego artysty stanowi wartość nie tylko plastyczną.

35 P. Potworowski, cyt. za: A. Wojciechowski, Piotr Potworowski, „Projekt” 1962 , nr 4, s. 3. 


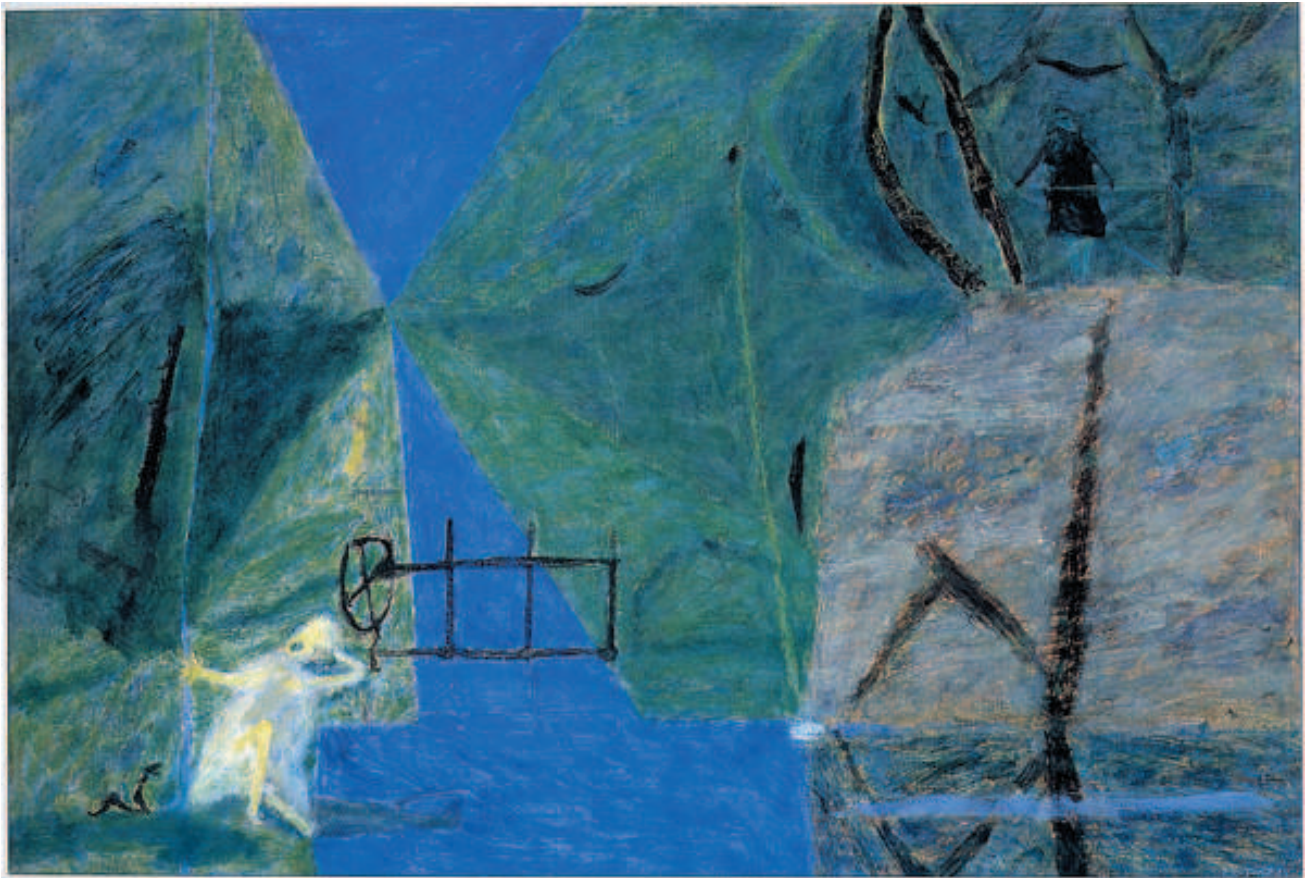

Il. 1. Piotr Potworowski, Kanat w lesie, 1957, olej (reprodukcja ze zbiorów Muzeum Narodowego w Warszawie)

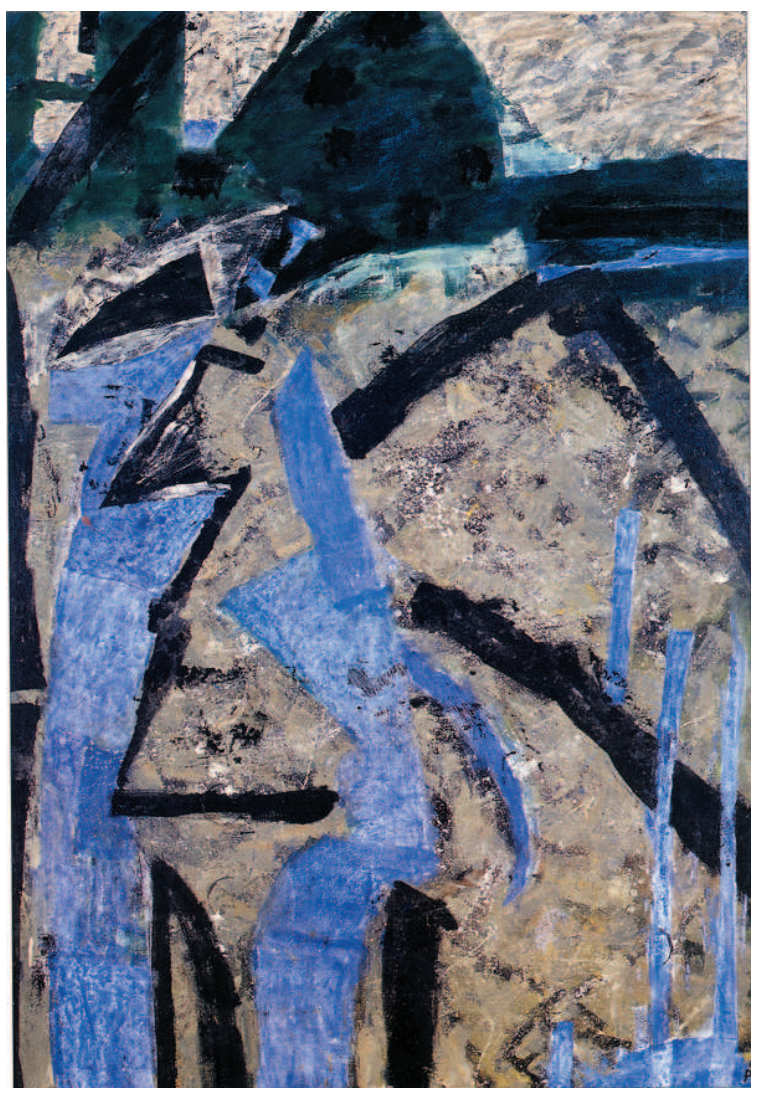

Il. 2. Piotr Potworowski, Wodospad w Niedzicy, 1960, olej (reprodukcja ze zbiorów Muzeum Narodowego w Warszawie) 


\section{Summary}

\section{The Role of Space in Piotr Potworowski's Landscapes}

Piotr Potworowski is an artist favoured with two homelands, constitute the essence of all his artistic efforts. Before WWI, a Capsist and a Józef Pankiewicz's student, fascinated with Pierre Bonnard's and Henri Matisse's paintings, a student of Fernand Léger, after the war Potworowski settled in England where he devoted himself to intensive work as an artist (he became a member of prestigious London Group) and a teacher (he became a professor of Bath School of Art and Design, now Bath Academy of Art in Corsham). Versatility of graphic expression of Piotr Potworowski: painting, drawing, spatial compositions, stenography had their counterpart of a different artistic mode, namely words. Poems, letters, extremely precious notes from his sketchbooks, miscellaneous casual remarks allow to look into his 'beautiful mind' and invite to explore the artist's most inner experiences and emotions, accompany plastic realizations showing their hidden depths. Potworowski's paintings are the evidence of his constant struggle with the space, the form, and the colour. Emotions, moments, or impressions submitted to artistic synthesis, have been converted into timeless values, codes enchanted onto canvas. This discussion refers to landscape painting by Piotr Potworowski, the uniqueness of which explains to large extent the artist's attitude to the issue of space. Potworowski perceived the canvas in purely painter's categories: light or the hue of the space. Potworowski's idea of space is the consequence of several most crucial rules that the tried to follow. First, breaking with the tradition of painting from one point, the artist treated a landscape as a sum of subjective and objective occurrences; all that he saw and felt he converted into "an appropriate painterly fact." In this context, he tried a new organization of space in his paintings; spatial relations became the result of 'deeper seeing'. The second rule was individual coding spatial elations he observed and tamed. In the artist's works space is not space 'found', or not merely found, but filtered though the master's sensitivity, generalized, and verified by time. This temporal distance, either several hours or 
several days long, allowed for the synthesis and had the crucial role in the creation process. The process that for Potworowski was first and foremost of intellectual nature, and could only result in some artistic manner. Thirdly, space on Potworowski's canvas is the effect of proper chromatic solutions, the ability of building unlimited spatial relations using several colourful planes. The meaning of the object is important only if it interacts with other objects creating new spatial categories. 